Journal of Law \& Social Studies (JLSS)

Volume 1, Issue 1, pp 27-38

www.advancelrf.org

\title{
Framing of Drone Attacks in Pakistani Elite Newspapers' Editorials: A Comparative Analysis of Dawn and The News
}

\author{
Muhammad Nosherwan Bukhari \\ BS Student (2009-2013) \\ Department of Communication Studies \\ Bahauddin Zakariya University, Multan \\ Samia Manzoor \\ Assistant Professor \\ Department of Communication Studies \\ Bahauddin Zakariya University, Multan \\ Samia.manzoor@bzu.edu.pk \\ Dr Muhammad Ashraf Khan \\ Professor \\ Department of Communication Studies \\ Bahauddin Zakariya University, Multan \\ ashraf_1963@yahoo.com
}

\begin{abstract}
Drone attacks in Pakistani territory have been a subject of discussions and debates from a very long time. This study attempts to explore the treatment of drone attacks in editorials of elite Pakistani English press i.e. Dawn and The News. The study has three dimensions: frequency of occurrence, frames and placement. It was found that the Dawn published more editorials about drone attacks from $1^{\text {st }}$ October 2012 till $31^{\text {st }}$ March 2013. Unfavorable frame was the most frequently used frame to discuss drone attacks in the editorials of both national dailies. Moreover it was established that Dawn although published more editorials about drone attacks but sometimes this issue was also discussed in lead articles and editorial notes. On the other hand The News always discussed the issue of drone attacks in lead articles. It was concluded that both the newspapers gave significant coverage to the issue of drone attacks in their editorials. Most of the editorials were condemning America for violating the sovereignty of Pakistan thus presenting America in an unfavorable frame.
\end{abstract}

Keywords: Drone Attacks, Framing, Pakistan-US relations, Dawn, The News, War on Terrorism, opinion of press on war on terrorism.

\section{INTRODUCTION}

World has shrunk due to the expansion of information technology and media. Easy access to information has increased the awareness of public about different national and international issues. The power of media to build or change the opinion has increased the importance of news media.

Media also changes our opinions and mind sets because we are dependent on media information. We get to know about latest happenings all over the world through media right from our room. Private media has widened the information and factual details about different aspect of almost everything. Like electronic media; print media is also very important and influential for public. 
In the modern times, $9 / 11$ was the most frightening event among all. And the reactions faced by this event were also disastrous. According to 9/11 commission report, evidences explored that Osama Bin Laden and Al-Qaeda were behind this attack and it was proved that none of $9 / 11$ activist was Pakistani.

Targets who were considered involved in the attacks of September 11, 2001 were identified and killed by United States. Two of the most active agencies of United States in counter terrorism and which adopted these scandalous tactics were Pentagon and the CIA. Both of these agencies were an indispensible part of the battle action adopted against Iraq and Afghanistan, Somalia, Yemen and Pakistan. When Mr Obama assumed office of president in 2009, the number of target killings increased tremendously, especially with the help of drone strikes on the targets of Taliban and al Qaeda. But special missions of United States against terrorists also contributed a lot in killing or capturing targets. Killing of The Osama Bin Laden and Anwar Al-Awlaki in May 2011 and September 2011 respectively are successful examples of US killing missions. The point of view of the White House is quite different as compared to the critics version, who denounce these acts while White House personnel refer these missions as victories against terrorism.

Dawn and The News are the two elite and prestigious English newspapers of Pakistan, so the editorials of these two newspapers are selected for comparison and analysis. The present study attempts to explore the framing of drone attacks.it tries to find out the kind of content and language being used by these two newspapers. Moreover it also tries to find out how much space is used by them for editorials regarding drone attacks.

\section{Statement of the Problem}

Media effect is a very indispensible part of communication studies research. But equally important is the content researches which media shows. Drone attacks are one of the major problems which Pakistan is facing from a very long time. And definitely America is held responsible for the consequences which Pakistanis are countering due to drone strikes. Pakistani media does have a very strong stance regarding drone attacks. But there is no doubt that different media outlets have varying policies towards certain issues. The News and Dawn are two elite newspapers of Pakistan. It is considered important to investigate the editorial policy of these two newspapers regarding such an important issue which Pakistan is facing.

\section{Objectives of the Study}

1) The study attempts to explore the extent to which the Pakistani English press covered the drone attacks.

2) This study also investigates the frames used for drone attacks by these newspapers during the study period.

3) The study investigates major difference in placement of drone attacks in Pakistani English.

\section{Significance of the study}

The research on media effects has increased tremendously in recent tears but news framing is such a part of media effects research which has received very petite attention. Framing research has gained momentum only a couple of decades ago. But very few researchers have endeavored in the area of political outcomes of news framing. It is imperative for the information to have a context, which will provide it meaningfulness and rationality. This study investigates that in which perspective Pakistani elite press portray drone strikes. What kind of frames Pakistani media is using friendly, foe, or either it is adopting a neutral stance. The present study focuses on the editorials of Dawn and The News, two elite newspapers of Pakistan, to analyze their framing and slant in the specific time period which is selected to conduct this research.

Editorials are thought to be a very vital component of newspapers which contribute enormously in constructing and molding public opinion of elites, and masses. In this study the researcher will try to explore the framing used by both newspapers in Pakistan while covering the stories regarding drone attacks in Pakistan. 
The study is very important in tracing the stance of Pakistani elite press regarding America's drone attacks. By reviewing this, the study could help in better understanding of the current direction of the Pakistani press towards drone strikes. As this study is analyzing the editorials of Dawn and The News, so it will be helpful in identifying the policy of both of these elite newspapers towards coverage of drone attacks. The study will also try to investigate the difference between the coverage given to this devastating issue by these newspapers to dig out whether they cover it in the same way or is there any difference in the coverage given to drone attacks by them.

\section{LITERATURE REVIEW}

Davies (2009) found that after holding the office of president of United States during his very first press conference, which took place on February 9, Barak Obama tried to give justifications about continuous drone attacks through reaper and predator in Pakistani territory. 340 persons have already murdered in these strikes United States Department of Defense hold this stance that due to these attacks many leading personalities of Al-Qaida and Taliban have been killed. The report also gave the facts that many innocent noncombatants in which children and women are also included who were living peacefully in the country have been victimized. He also claimed that drone strikes are illegal and Pakistani press condemns it. It is against humanitarian international law. Pakistani media also condemned this predator war started by US in the name of war on terror. And due to this war no doubt the many terrorists have been killed but innocent people are also being victimized.

Fair explored that Pakistanis felt very ashamed and depressed after the incident of 2nd May, the day of Bin Ladin's death. This can be fearful that such sort of incidents or drone strikes could be made by other enemies of Pakistan such as India, Israel and United States on our different areas and nuclear assets. Pakistani armed and intelligence forces are feeling very disgraced by such sort of incidents because they are not protecting their people from these drone strikes which is strongly fated by media of Pakistan.

Stewart and Birsel (2009) explored after analyzing 9 months of Obama's administration, U.S conducted 39 drone attacks in Pakistan along with the attack on Baitullah Meshod in August 2009, which was a considered a big victory of CIA, but very badly portrayed by Pakistani media. During this mission Pakistan suffered the violation of her sovereignty as well as killing of innocent citizens. But drones are important for United States because usage of these drones saves their pilots' lives thousand miles away.

Mayer (2009) analyzed that Bruce Riedel, a Former CIA Officer discussed the disadvantages of drones in an article entitled "is the drones programs helping or hurting". He says that U.S is thinking that drone are the only way to compel Afghanistan and Pakistan but these are like apiary, which will create more bees but Pakistani media's stance is that drones are hurting more than helping.

Jones et.al (2011) expressed that United States has tremendously increased the practice of UAVs also referred as predator drones in the remote region of Afghanistan and Pakistan. Experts consider the practice of drone strikes as lawful and proficient for targeting radicals but many criticize it as an unethical practice and against international law in which many innocent civilians are being killed. In this study, Jones et.al proposes an examination of the gap present in media framing of the drone strikes in U.S media and foreign media.

Radson et.al, (2009) summarized the opinion of CIA drones program experts, that these strikes are not illegal. CIA drones wing and other similar campaigns also being abused by many for having such opinion. The reason is that residents of foreign countries are also residing close to the strike locations. This is also important to say that violation of international law can also create difficulties for American officials. Some critics claim that CIA drone attacks have caused civilian causalities at the rate of 20:1 and 50:1.

Llenza (2011) analyzed that Islamabad has little or no control over the tribal areas where UAVs are being strike and the power of Taliban has been grown since they are relocated into the area. These strikes are very much condemned by Pakistani press. Furthermore, predator drones have proven to be an effective anti-terrorism tool as compared to Israel's own target killing program and he added that the United States need to actively defend its position. This antiterrorism activity is predestined by Pakistani media from a very long time but still we see no impact. In this study he explored that Pakistan has no mechanism to stop these terrorist activities by Taliban group that's why it is asking 
America for help and America is using powerful technology to counter the suspected militants in the tribal areas. But now these attacks are very much discredited by Pakistani media as it's a violation of sovereignty of the state.

The achievements of drone strikes compelled the Bush Administration to think that if a small number of drones can be so successful in killing targets more strikes will definitely be even more fruitful but it is against the national integrity of Pakistan and is being condemned by the state very much which has made no influence on these drone attacks yet.

Blum et.al. (2010) concluded that the Supreme Court's verdict showed distress over the insecure and alarming situation the innocent residents were facing in US operations of targeted killings operations with the help of UAVs. When this petition was filed the ratio of killings of militants and civilians was one to three. It means that for every militant who was killed three civilians were also being killed. And the ratio of civilians who were getting hurt was 2:3. So it means that drone strikes are not good enough and it is discouraged by also media of Pakistan. Drone strikes have gained momentum since 9/11 by United States to targets terrorists in Pakistan, Afghanistan, Yemen, and Iraq. These operations have killed many al Qaeda leaders.

Shah discussed in his article that it must also be understood that for Pakistan, U.S. drone strikes are proving to be more damaging than helpful. Media of Pakistan is arguing against these drone attacks and its illegality. It is totally unjustified act of United States that what happened there on September 11, 2001 they are inflicting the same on Pakistani citizens with the help of drones. Baitullah Mehsud, once threatened that radicals will not stop undertaking acts of terrorism on Pakistani territory if United States would not stop targeting them through drones. Media of Pakistan is also portraying the reality. And this reality is not some good news but media is unable to make any difference yet.

Aurangzeb (2013) investigated that Pakistan never filed its case of innocent killings to any international court of law, hence it is assumed that there is some so it is assumed that there is some 'clandestine pact' between the governments of United States and Pakistan. If there is some pact between the two governments, then why Pakistani press is not discussing it? It is also presumed that Pakistani officials secretly approve US drone strikes. This pact enables CIA to use arms in Pakistani territory and notifying Pakistan after launching missiles. This is the justification which US authorities present to launch drones. Pakistan has repeatedly discouraged drone strikes and invited US government officials to Pakistan. In his article he added that the responses of Pakistani government officials do not show any support for US drone attacks in Pakistan.

Paracha et.al, (2011) summarized in his study that media frames can be made intentionally, but sometimes it is made by readers themselves. Furthermore Pakistan's position is very vulnerable after $9 / 11$ attacks and she has repeatedly told to the international community to the people of Pakistan that it has not any relation and link with Al-Qaeda, Taliban and their terrorist activities. In the past, Pakistan had to be an ally with the U.S in war on terror to make the world believe on its position, but still after doing all this Pakistan is facing much destruction in their tribal areas till now in the form of pilotless drones. In this critical situation Pakistani media frame these drone attacks negatively.

In this regard, Pakistani official claims that more than 700 were killed in 2009, and Pakistani press denounces drone attacks strictly but the U.S investigations found that less than 30 noncombatants were exterminated from May 2008 to May 2010.

Currier (2013) explored that US government launched first drone on in Yemen in 2002 on al Qaeda. These drones were taken to several of the international covert bases secretly. These secret drone strikes caused hundreds of deaths in Pakistan which is also endorsed by Bureau of Investigative Journalism. Furthermore Currier expressed that the US government officials have said in their dialogues that all these radicals are very threatening for United States so their killing seemed more reasonable instead of capturing.

Williams (2010) concluded in his study, that the covert drone strikes were initiated in 2001 in tribal regions of Pakistan to counter terrorists. Not very much at that time but now it is very criticized by Pakistani press they consider it as an attack on the sovereignty of Pakistan. Although it is viewed as greatest efficient instrument in combating radicals in America but actually it is against the sovereignty of Pakistan. The article also pointed out the third aspect that many 
Pashtun people who are natives of tribal areas endorsed drone strikes to combat Taliban who have been victimized by Taliban in recent years.

Shaw, R. et.al (2010) discusses the reasons behind U.S drone warfare being going on in the Federally Administered Tribal Areas (FATA) of Pakistan. It is obvious that all people living in these tribal areas are not linked with Taliban and Al-Qaeda but the truth is that there are also those who are extremists and have linkages with terrorist groups. Pakistani media also focuses on this violation of international law which America is responsible for. But whatever Pakistani media is doing to condemn these strike it has no effect on America's policy about drone attacks. And this entire situation is not appreciated by Pakistani media. As a result of these continuous attacks by these machines in Pakistani tribal areas cause lethal collaboration between regulation and machinery.

\section{Research Questions}

RQ1: How many (frequency of occurrence) editorials on drone attacks were published by Dawn and The News during six months from October 2012 till March 2013?

RQ2: What were the frames used by Dawn and The News?

RQ3: What is the placement of drones in the editorial page of Dawn and The News?

\section{Research Hypothesis:}

$\mathbf{R H}_{1}$ : The News will publish more number of editorials on drone attacks from $1^{\text {st }}$ October 2012 to $31^{\text {st }}$ March 2013 than Dawn.

$\mathbf{R H}_{2}$ : It is more likely that unfavorable frame will be most repeatedly used by The News and Dawn for America in their editorials from $1^{\text {st }}$ October 2012 to $31^{\text {st }}$ March 2013.

$\mathbf{R H}_{3}$ : It is more likely that The News will place editorials related to drone attacks more often in its lead articles as compared to Dawn.

\section{METHODOLOGY}

\section{Research Design}

Quantitative content analysis is adopted as the sole data collection technique in the present research to study the editorials of The News and Dawn Walizer and Weinir (1978) define it as a well-planned process developed to analyze the content of documented information. According to Kerlinger content analysis is the name of a procedure of analysis and learning messages in a methodical, unbiased and numerical way so that variables could be measured. That's why content analysis is selected as the core method for data analysis. The content is divided into three categories i.e. favorable, unfavorable and neutral. The operational definitions of the categories are available in the forthcoming portion. Meeting with the requirements of research questions and hypotheses quantitative content analysis is considered the best for the present research.

\section{Population}

The editorials of Dawn and The News on drone strikes, published during a period of six months from $1^{\text {st }}$ October 2012 to $31^{\text {st }}$ March 2013 are selected as the population of this study.

\section{Sampling Procedure}


Two leading newspapers Dawn and The News are the universe of the current research. It is a census study as all the newspapers on drone strikes were included in population and were analyzed. That's why no specific sampling procedure was adopted and no sample was selected but the analysis was carried out on the entire population.

\section{Unit of Analysis}

Whatever is defined or examined through content analysis is called unit of analysis. The present study is analyzing three different variables i.e. Frequency of occurrence, slant \& frame and presentation. So the units of analyses are different for all the three variables.

Frequency of occurrence: Title and opening paragraph will be considered as unit of analysis to identify either the editorial is related to Drone attacks or not.

Frame: Every sentence of the editorial regarding drone attacks will be the unit of analysis to investigate the frame of the entire editorial.

Placement: $\quad$ The whole editorial will be analyzed to see its placement on the editorial page.

\section{Operational Definition of Categories}

After conducting a rigorous literature review and consulting with various experts the researcher made three different categories to check out the framing of drone attacks. The operational definitions of these are given below,

\section{Unfavorable}

Any sentence that includes any explicit or implicit meaning which gives an impression of

that

- $\quad$ These strikes are illegal and against sovereignty of Pakistan.

- Deaths of innocents, more harmful for innocents than beneficial for target killing.

- $\quad$ America is not abiding the international law.

- America has inflicted war on Pakistan.

- Condemning drone attacks.

Favorable

- Drones attacks are legal.

- $\quad$ Effective tool to target suspected militants accurately.

- $\quad$ Pakistan is giving information about suspected militants in the state.

\section{Neutral}

- Just giving information about drones.

- $\quad$ Neither favoring nor against drones.

- $\quad$ Statements of threats by Al-Qaida and Taliban.

\section{Placement}

It refers to the place in which both the newspapers are placing the drone attacks editorials, whether as leading articles or as editorial notes.

\section{DATA PRESENTATION AND ANALYSIS}


RH1) The News published more editorials on drone attacks during six months (the study time period) as compared to Dawn.

\begin{tabular}{|c|c|c|c|c|c|c|c|}
\hline & Oct 2012 & Nov 2012 & Dec 2012 & Jan 2013 & Feb 2013 & Mar 2013 & Total \\
\hline The News & 1 & 1 & 0 & 1 & 0 & 1 & 4 \\
\hline Dawn & 1 & 1 & 1 & 3 & 1 & 1 & 8 \\
\hline
\end{tabular}

\section{Interpretation:}

The study explores that there were 8 (66.66\%) editorials published in Dawn and 4 (33.33\%) were published in The News. In The News editorials were published on each of the below mentioned dates, October 22, November 20, January 5, and March 17 while in Dawn, editorials were published on October 9, November 8, December 27, February 7 and March 18, while in the month of January 3 editorials were published on January 5,18 and 22,. So the findings do not support researcher's $1^{\text {st }}$ hypothesis. Out of a total of 12 editorials which were published in both of these newspapers only 4 appeared in The News.

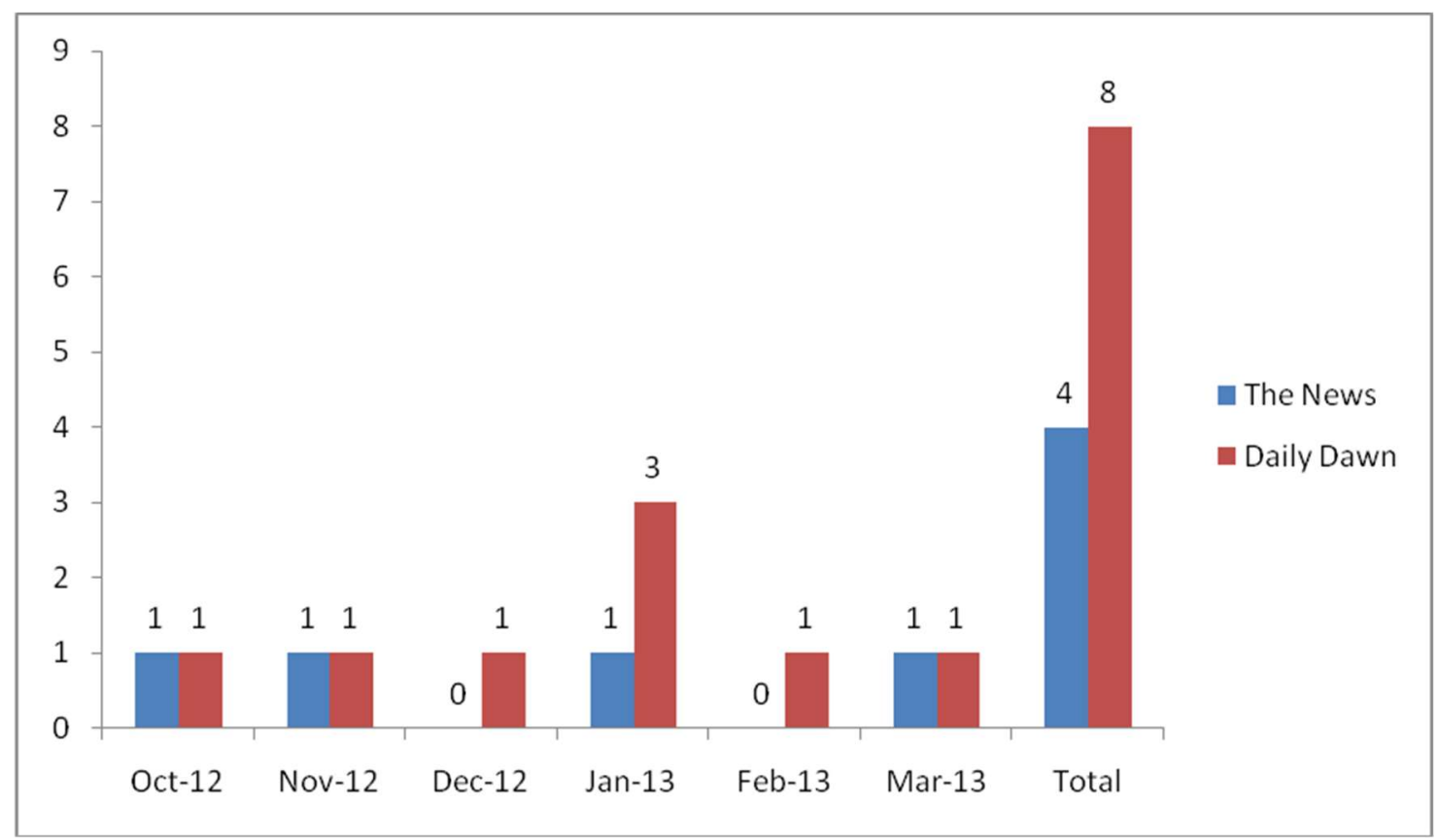


$\mathbf{R H}_{2}$ ) It is more likely that unfavorable for America frame will be most repeatedly used by these two newspapers in their editorials during six months (the study time period).

\begin{tabular}{lllllllll}
\hline & & OCT & NOV & DEC & JAN & FEB & MAR & TOTAL \\
\hline The & Favorable & 0 & 0 & 0 & 4 & 0 & 2 & $\mathbf{6}$ \\
News & Unfavorable & 10 & 12 & 0 & 9 & 0 & 12 & $\mathbf{4 3}$ \\
& Neutral & 3 & 5 & 0 & 4 & 0 & 3 & $\mathbf{1 5}$ \\
\cline { 2 - 3 } & Favorable & 2 & 2 & 0 & 4 & 5 & 2 & $\mathbf{1 5}$ \\
& Unfavorable & 10 & 13 & 1 & 24 & 12 & 10 & $\mathbf{7 0}$ \\
\hline & Neutral & 1 & 0 & 13 & 10 & 0 & 0 & $\mathbf{2 4}$ \\
\hline
\end{tabular}

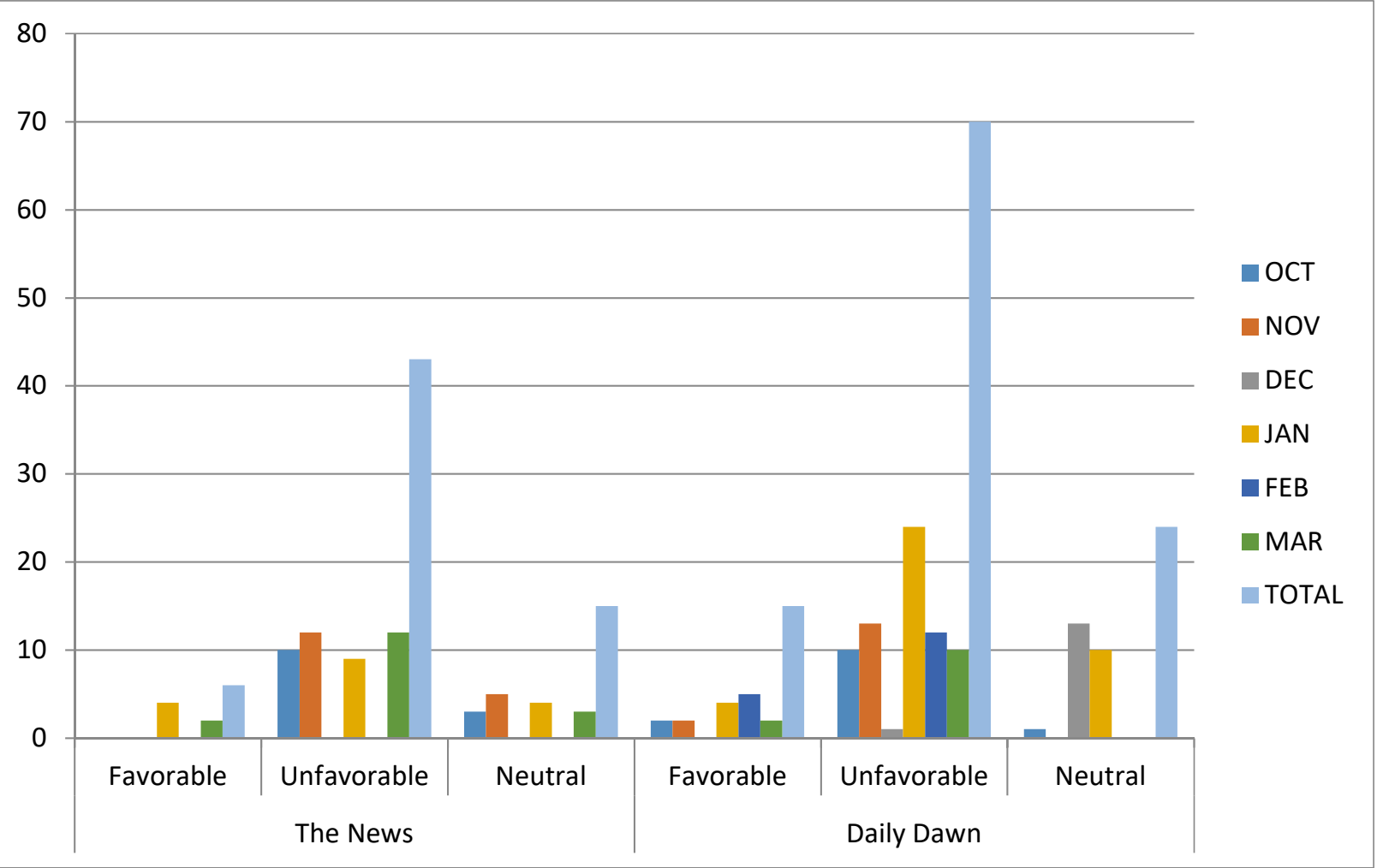

\section{Interpretation:}

The study explores that unfavorable for America frame was the most frequently used frame by these two dailies. A total of 64 sentences were found in the editorials of The News regarding America and 109 sentences were found in 
Dawn. Out of the total 64, 43 sentences in The News were identified as supporting an unfavorable frame. Only 06 sentences were coded as presenting America in a favorable frame and remaining 15 were neutral. It shows that The News published $67.19 \%$ sentences in an unfavorable frame. So the unfavorable frame was most consistently used frame in the editorial coverage of The News regarding America and drone attacks. On the other side Dawn published a total of 109 sentences in editorials regarding this issue, out of which 70 were unfavorable, 15 were favorable and the remaining 24 were neutral. Dawn published $64.22 \%$ sentences in an unfavorable frame. It is clear from the above mentioned facts that unfavorable frame for America was most frequently used in the editorial treatment of these newspapers. Favorable and neutral frame of each newspaper collectively is less than the unfavorable slant. So the results support this hypothesis.

RH3) It is more likely that The News places drone strikes more often in its lead article as compared to Dawn.

\begin{tabular}{llll}
\hline THE NEWS & & DAWN & \\
\hline Leading Article & Editorial Note & Leading Article & Editorial Note \\
4 & 0 & 6 & 2 \\
\hline
\end{tabular}

\section{Interpretation:}

The study explores that The News placed all editorials (100\%) as leading articles in which 1 was published on each of the below mentioned dates October 22, November 20, January 5 and March 17 while Dawn placed $75 \%$ editorials as leading articles on the below mentioned dates October 9, November 8, December 27, 2 in January on 5 and 22, 1 on February 7 and $25 \%$ as editorial notes, in which 1 is published on January 18 and 1 on March 8 . So this this data strongly supports the hypothesis.

\section{CONCLUSION \& DISCUSSION}

The increased number of drone attacks in Pakistan is against Pakistan's sovereignty, integrity and international law, because for this type of attacks one has to get permission first from the state where the attacks are going to take place. After 9/11 these drone strikes were started by the US as they call it war against terrorism. The US has been striking drones in Afghanistan, Iraq, Yemen and Pakistan from a very long time. Perhaps America is attacking the terrorists of Al-Qaida and Taliban groups but it is also very true that due to these attacks hundreds of civilians have also lost their lives.

If we discuss it from American perspective, they call it legal and an effective tool for killing dangerous terrorists like Taliban. A UN's special rapporteur on Human Rights, Ben Emerson said that these drone attacks on Pakistani soil are a violation of the country's sovereignty and these are illegal. But there are also some points which indicate that Pakistan and America have some secret agreement regarding drone attacks, furthermore there is another third point of view which shows that Pakistan is giving information about suspected militants in the tribal areas.

The objective of this research work was to study the frames used for drone attacks as presented by Dawn and The News. In this study the editorials of Dawn and The News, which are two elite English dailies of the time period, $1^{\text {st }}$ Oct 2012 to $31^{\text {st }}$ Mar 2013, have been chosen. The researcher wanted to know that which kind of coverage these two newspapers are giving to Drone attacks. While these attacks are being condemned by the entire world sitting out there the researcher reveals the way in which elite Pakistani media is treating this issue. Are they covering the present situation? If yes which paper is showing more interest in Drone attacks Dawn or The News? The importance given to the issue was checked along three parameters: frequency of occurrence, frames and placement.

It was found out that during the six months' time period, from October 2012 to March 2013, 12 editorials were collectively published by these two dailies, 8 in Dawn (66.66\%) and 4 in The News (33.33\%). 
Researcher's $1^{\text {st }}$ question was how many editorials on drone attacks were published by these two newspapers during six months (Oct. 2012 to March 2013)?

The study confirms that $66.66 \%$ editorials were published in Dawn and $33.33 \%$ editorials were published in The News regarding drone attacks during six months (the study time period). It shows that the frequency of occurrence of this issue in editorial treatment is far greater in Dawn than in The News. It shows that along the parameter of frequency of editorials, the number of editorials published in Dawn is greater than The News. The frequency of occurrence of editorials regarding the issue of drone strikes in Dawn is twice greater than The News. January was the only month where three editorials were published in Dawn. On the contrary there was no month when The News published editorials regarding this issue more than one.

Researcher's $2^{\text {nd }}$ question was what were frame used by both newspapers to portray America?

The study explored that unfavorable frame was mostly used for America by these two dailies, $64.88 \%$ unfavorable and frame was used by Dawn and $67.18 \%$ was used by The News. It means that although number of editorials published in The News was much less than Dawn yet the treatment regarding frame was slightly different in both the newspapers, giving The News lead in publishing slightly higher ratio of unfavorable frame for America. Both the newspapers strongly condemned America holding it solely responsible for the damages caused by drone strikes. On the contrary Dawn used more favorable slant and frame for America giving $13.76 \%$ of its total coverage as compared to The News which only gave $9.32 \%$ favorable coverage to America

Researcher's $3^{\text {rd }}$ question was, what is the placement of editorials regarding drones in these newspaper's editorial pages?

The study explores that The News placed all editorials (100\%) related to drone attacks as leading articles while Dawn placed $75 \%$ editorials as leading articles and $25 \%$ as editorial notes. This shows that both the newspapers had different editorial policies regarding Drone attacks even in the matter of placement. It can be said that Dawn was trying harder to keep the issue alive so it discussed it on all the incidents regarding drone attacks no matter big or small in its editorials and for this purpose sometimes the content was placed as lead article and sometimes as editorial note. While on the other hand The News although discussed the issue of Drone attacks lesser than Dawn but always gave it place in the lead article treating it as the most important issue of the day.

As mentioned earlier this is all related to the newspapers policy. But it is quite obvious that both the newspapers satisfied the readers to their fullest by treating the issue of Drone attacks adequately.

\section{References}

Aurangzeb (2013). US Drone Strikes in Pakistan: International Law Perspective, Retrieved on April 28,2013 from www.pakistankakhudahafiz.com/2013/01/30/us-drone-strikes-in-pakistan-international-law-

perspective/\#.uyonsai3ubm

Blum, G \& Heymann, P. B. (2010). Laws, Outlaws, and Terrorists: Lessons from the War on Terrorism. MIT Press Ebooks

Currier, C. (2013). Everything you need to know about drone strikes, published on January 23, 2013. Retrieved on May 6, 2013 from www.pbs.org/wnet/need-to-know/security/everything-you-need-to-know-about-dronestrikes/16098/

Couldry, N. \& Curran, J. (2003). Contesting Media Power: Alternative Media in a Neworked World. US: Rowman \& LittlefieldPublishers, Inc.

Davies, Nicolas J. S. (2009). The Caroline case and American drone strikes in Pakistan, Peace Review: Journal of Social Justice, 21(4): 429-436 DOI: 10.1080/10402650903323397 
Fair, C Christine. (2011). Try to see it my way, Foreign Policy, Retrieved on April 27,2013 from http://afpak.foreignpolicy.com/posts/2011/05/24/try to see it my way

Hoffman, B. (2011). Rethinking Terrorism and counterterrorism since 9/11. Studies in Conflict and Terrorism, 25(5), 303-316: DOI: 10.1080/105761002901223

Jones et.al (2011).Differential News Framing of Unmanned Aerial Drones: Efficient and Effective or Illegal and Inhumane? APSA 2011 Annual Meeting Paper. Available at SSRN: http://ssrn.com/abstract=1900579

Kellner, D. (2003). From 9/11 to Terror War: The Danger of the Bush Legacy. US: Rowman \& LittlefieldPublishers, Inc.

Kerlinger, F.N. (1986) Foundation of behavioral research. (3 ${ }^{\text {rd }}$ Edition): Holt, Rinchart \& Winston. Inc., American Problem Series, New York, NY.

Klaidman, D. (2012). Kill or Capture: The War on Terror and the Soul of the Obama Presidency. Boston, New York: Houghton Mifflin Harcourt

Landau, M. J. et.al. (2004). Deliver us from Evil: The Effects of Mortality Salience and Reminders of 9/11 on Support for President George W. Bush. Personality and Social Psychology Bulletin, 30(9): 1136-1150. DOI: $10.1177 / 0146167204267988$

Llenza,M. (2011). Targeted killings in Pakistan: A Defense. Global Security Studies, 2(2). Retrieved on April 27,2013 from http://globalsecuritystudies.com/Targeted\%20Killings.pdf

Mayer,J. (2009). The predator war: What are the risks of CIA's covert drone program. Retrieved on April 20,2013 from http://newyorker.com/reporting/2009/10/26/091026fa fact mayer

Paracha, S.A et.al (2012) Framing of drone attacks in Pakistani elite press: A comparative study of Dawn and the Nation. Mediterranean Journal of Social Sciences. 3(1): 471-482. Doi: 10.5901/mjss.2012.03.01.471

Radson, Murphy. (2009). Due Process and Targeted Killing of terrorists. An unpublished paper presented at Texas Tech Law School. Retrieved on April 25,2009 from http://www.jnslp.com/wp-content/uploads/2012/01/TheEvolution-of-Law-and-Policy-for-CIA-Targeted-Killing.pdf

Rodrik, D. (1998). Has Globalization Gone Too Far. Challenge, 41(2): 81-94. http://www.jstor.org/stable/40721822

Ronald Shaw, I. G. and Akhter, M. (2012), The Unbearable Humanness of Drone Warfare in FATA, Pakistan. Antipode, 44: 1490-1509. DOI: 10.1111/j.1467-8330.2011.00940.x

Singleton Jr, et.al. (2005) Approaches to Social Research, (fourth edition). New York, NY, US: Oxford University Press.

Shah, S. A. (2010) War on terrorism: self-defense, operation enduring freedom, and the legality of U.S drone attacks in Pakistan. Washington University Global Studies Law Review, 9(1): 77-129. Retrieved on April 28,2013 from http://openscholarship.wustl.edu/cgi/viewcontent.cgi?article=1041\&context=law_globalstudies

Sparks, G.G. (2006). Media Effects Research: A Basic Overview, (2 ${ }^{\text {nd }}$ Edition). US: Thomas Wadsworth

Stewart, P. \& Birsel, R. (2009). Analysis-under Obama, drone attacks on the rise in Pakistan. Reuters. Retrieved on April 20, 2013 from http://www.reuters.com/article/2009/10/12/idUSN11520882 
Walizer, M.H., \& Wienir, P.L (1978), Research Methods and Analysis: Searching for relationships. NewYork: Harper \& Row.

Williams, G.B (2010) The CIA's covert Predator Drone War in Pakistan, 2004-2010: The history of an Assassination campaign. Studies in Conflict and Terrorism, 33(10): 871-892. DOI:10.1080/1057610x.2010.508483 